\title{
The Realization of Intensifiers in Banyumas Dialect
}

\author{
Chusni Hadiati \\ English Department, Faculty of Humanities, Jenderal Soedirman University, Indonesia
}

\begin{abstract}
Linguistic provides a set of devices to express referential and affective functions. Intensifier as a linguistic device is generally found in all languages and it has various linguistic forms. In Banyumas dialect, a substandard of Javanese language, intensifier is basically used to intensify something. Banyumas dialect or Banyumasan is primarily spoken along Serayu River. Banyumas dialect is different from Javanese language in respect of phonological features and lexical items. Speakers express their intensity by using several linguistic devices including lexical items and reduplication. General lexical items consist of bangèt and pisan. bangèt and pisan experience degree of modification as they are attached to non-binary properties predicate. Specific lexical items include rea, regeng, leder, njilep, cirut, lecit, kecu, kethuwek. Reduplication is realized into full reduplication and partial reduplication. Partial reduplication employs reduplication with vowel change and reduplication of the final syllable of the stem. Grammaticalization happens to Partial reduplication with vowel change. Data is gathered from 250 recorded conversations between male and female speakers containing intensifiers. As intensifier is among the most rapid of linguistic element, this article reveals the realization of intensifiers in Banyumas dialect.
\end{abstract}

Index Terms - intensifier, Banyumas dialect, intensity, lexical items, reduplication

\section{INTRODUCTION}

Intensifiers are generally found in natural language since speakers need it to enhance information among them. It focuses on affective functions as it does not carry significant referential content. It is commonly defined as linguistic devices that boost the meaning of a property upwards from an assumed norm (Quirk et al, 1985). It is also described as a modifier that gives no contribution to the propositional meaning of a construction but it increases its emotional meaning and it is also an adverb which maximizes or boosts meaning typically modifying adjectives or degree (Ito \& Tagliamonte, 2003). There are two types of adverbial intensifiers: maximizers (extremely, absolutely) and boosters (really, very). It is very common for speakers to emphasize their utterance intentionally for certain reasons.

Daily conversation is generally conducted in local variety or dialect. Chambers and Trudgill (1994, p. 3) define dialect as a substandard, low status, often rustic form of language, generally associated with the peasantry, the working class, or other group of lacking in prestige. Dialect is also a term which is often applied to form of language, particularly those spoken in more isolated parts of the world, which have no written form. Dialects are also often regarded as some kind of (often erroneous) deviation from a norm-as a variation of a correct or standard form of language.

Banyumasan or Banyumas dialect is a non-standard form of Javanese language which is mainly spoken along Serayu River (Koentjaraningrat, 1984, p. 23). Banyumasan which is used in Banjarnegara regency, Purbalingga regency, Banyumas regency, Cilacap regency and Kebumen regency (Barlingmascakeb) is basically stated as a dialect of standard Javanese spoken in Yogyakarta and Surakarta. Javanese language is grouped into Proto Austronesian language which is then divided into two groups: west and east. The west Proto Austronesian consists of: Malay language, Sundanese, Javanese, Balinese, Maduranese, Bugis, and languages in North Sulawesi and Philippines archipelago (Wedhawati et al, 2006, p. 9). Compared to standard Javanese, Banyumasan has some differences due to phonological and lexical features.

Wedhawati et.al (2006, p. 18) mention the characteristic of Banyumasan vowels compared to Standard Javanese vowels are as follows: (1) phoneme /i/, when /i/ occurs in a closed coda, it will be realized as [i] in Banyumasan, and [i] in Standard Javanese, (2) phonem /u/, when / $\mathrm{u} /$ occurs in a closed coda, it will be realized as [u] in Banyumasan, and [U] in Standard Javanese;(3) phoneme /a/, when /a/ occurs in an open coda, it will be realized as [a] in Banyumasan, and [0] in Standard Javanese.

TABLE 1:

THE REALIZATION OF STANDARD JAVANESE AND BANYUMASAN VOWELS

\begin{tabular}{|l|l|l|l|l|l|}
\hline No & Phoneme & Orthography & Standard Javanese & Banyumasan & Meaning \\
\hline 1 & /i/ & Pitik & {$[$ pitI?] } & [pitik] & chicken \\
\hline 2 & /u/ & Abuh & {$[$ abUh] } & [abuh] & abscess \\
\hline 3 & /a/ & Lara & {$[$ lor ] } & {$[$ lara?] } & ill \\
\hline
\end{tabular}


Regarding the differences in consonants between Standard Javanese and Banyumasan, Wedhawati, et.al (2006, p.18) further elaborate as follows: The characteristics of Banyumsan consonants are reflected in phonemes /b, d, g, k, and ?/. If they are compared to Standard Javanese, they will be realized as [p], [t], [k], [?], and [Ø]. Table. 2 displays the examples of the above elaboration.

TABLE 2:

THE REALIZATION OF STANDARD JAVANESE AND BANYUMASAN CONSONANTS

\begin{tabular}{|c|c|c|c|c|c|}
\hline No & Phoneme & Orthography & Standard Javanese & Banyumasan & Meaning \\
\hline 1 & $/ \mathrm{g} /$ & endhog & [ənd $\left.{ }^{\mathrm{h}} \curvearrowright \mathrm{k}\right]$ & [ənd ${ }^{\mathrm{h}} \mathrm{og}$ ] & egg \\
\hline 2 & $/ \mathrm{b} /$ & Ababe & {$\left[\mathrm{ab}^{\mathrm{h}} \mathrm{ap}{ }^{\mathrm{h}} \mathrm{e}\right]$} & {$\left[a b^{\text {h }} a b^{\text {h }} e\right]$} & mouth smell \\
\hline 3 & $/ \mathrm{d} /$ & Babat & [b $\left.\mathrm{b}^{\mathrm{h}} \mathrm{ab}{ }^{\mathrm{h}} \mathrm{at}\right]$ & {$\left[\mathrm{b}^{\mathrm{h}} \mathrm{ab}^{\mathrm{h}} \mathrm{ad}\right]$} & part of meat \\
\hline 4 & $/ \mathrm{k} /$ & Bapak & [b $\left.\mathrm{b}^{\mathrm{h}} \mathrm{apa} ?\right]$ & [b $\mathrm{b}^{\mathrm{h}}$ apak] & father \\
\hline 5 & $/ ? /$ & Ora & [ora] & [ora?] & no \\
\hline
\end{tabular}

From those two table above, it can be seen that the major differences in vowel is that Banyumas vowels tend to be front vowels and standard Javanese are tend to be back. As far as consonants are concerned, Banyumas consonants tend to be voiced consonants.

There are also some differences in Standard Javanese and Banyumasan lexical features as they are shown in table. 3. We provide some different lexical features found in Standard Javanese and Banyumasan

TABLE 3:

THE LEXICAL FEATURES OF STANDARD JAVANESE AND BANYUMASAN

\begin{tabular}{|l|l|l|l|}
\hline No & Standard Javanese & Banyumasan & Meaning \\
\hline 1 & Tela & boled & cassava \\
\hline 2 & Blonjo & becer & shopping \\
\hline 3 & Manthuk & bali & go home \\
\hline
\end{tabular}

Banyumasan is widely spoken in Banjarnegara regency, Purbalingga regency, Banyumas regency, Cilacap regency and Kebumen regency (Barlingmascakeb). However, it also used in Brebes regency, Tegal regency, and Pemalang regency as it is depicted by figure. 1. Below is the map showing the spread of Banyumasan.

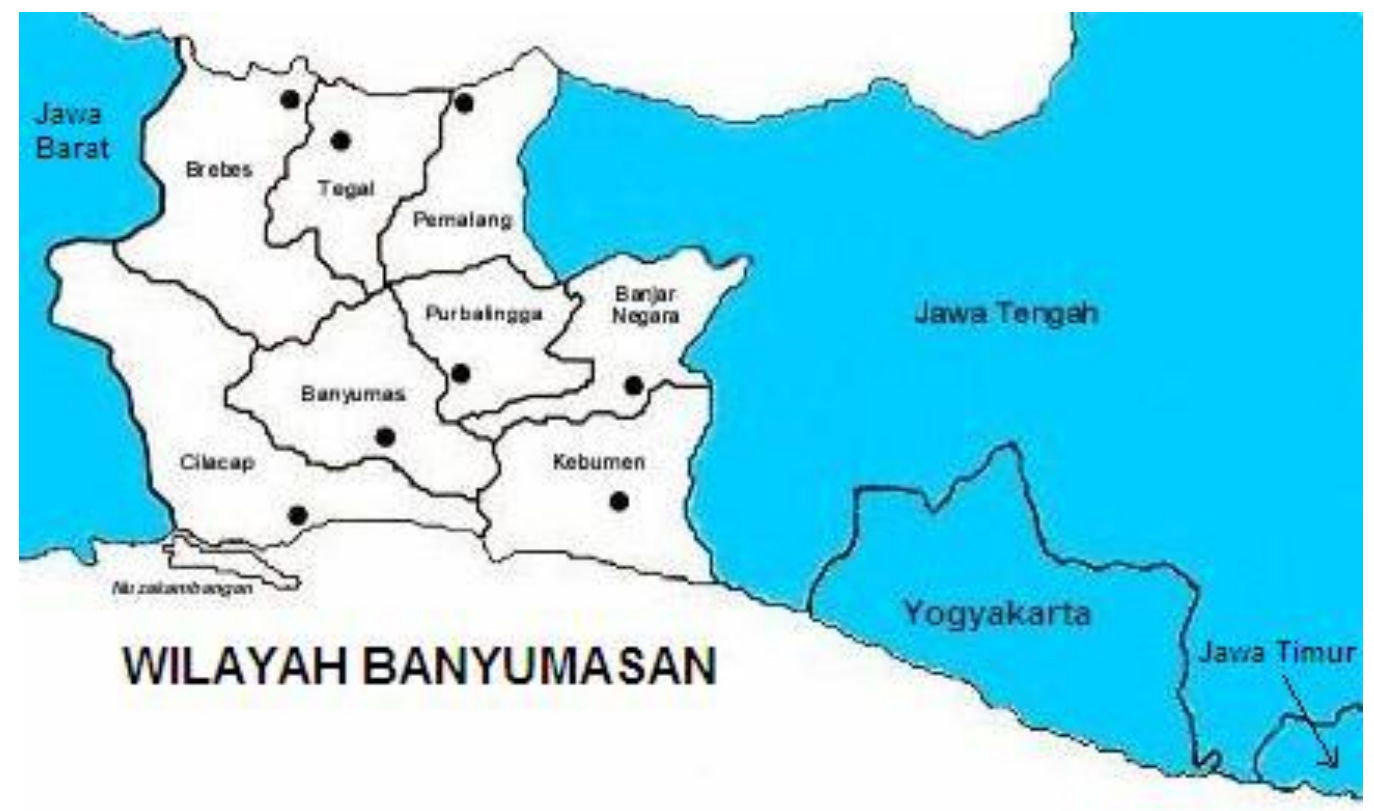

Figure1. The Spread of Banyumasan

Intensifier has become an interesting topic in linguistic research. It calls researchers' interest on intensifiers' semantics and intensifiers' usage in social interaction. Researchers on intensifiers' semantic have highlighted that boosting effects can be gained through different types of semantic operations and the context where intensifiers are used broaden further from the category of gradable expressions (McNabb, 2012; Beltram and Bochnak, 2013). Intensifiers' usage in social interaction has identified that the use of intensifiers is not distributed evenly across the social space, but it varies across macro-social categories, such as gender and age (Macaulay, 2006; Tagliamonte, 2008). Different from those two major topics in intensifiers' research, Eckert (2012) highlights that intensifiers are often exploited to build specific style and identities.

Brown (2014) presents a synchronic study on the grammaticalization of wicked and other intensifier in New Hampshire. She demonstrates that wicked is in the process of gramaticalizing through the mechanisms of desemanticization and extension. She concludes that wicked collocates widely with the Dixon Semantic Types, that it 
functions both attributively and predicatively, and that it is used in both positive and negative contexts- three indications of the first two mechanisms of grammaticalization, desemanticization, and extension. However, the data does not confirm nor deny the third nor fourth mechanism of grammaticalization, cliticization and erosion. Brown states that wicked is stereotypically used as an intensifier by New Englanders as it is commonly found in various regional product names, restaurant, and tourist merchandise, as well as in everyday speech (2014).

In addition to intensifiers' usage in social interaction, several researches have been conducted. They can be classified into two major categories. First, intensification systems are not stable and change rapidly in any speech community (Macaulay, 2006; Rickford, 2007; and Tagliamonte, 2008). Second, there is a tendency that the use of intensifiers varies across demographic categories. Those demographic categories especially focus on age and gender (Brown and Cortés-Torres, 2013; Sardabi and Afghari , 2015).

Brown and Cortés-Torres (2013) conduct a research on Puerto-Rican intensifiers which include bien and muy. The quantitative result shows that in informal, spontaneous, conversational Spanish, use of bien (86\%) as an intensifier for adjectives far outweighs use of muy (13\%) in frequency. In each generation, women use bien (88\%) more than men $(83 \%)$. The younger generation (both men and women) have a higher frequency of use (91\%) of bien than the older generation $(85 \%, 82 \%)$.

A recent study conducted by Sardabi and Afghari (2015) shows the use of intensifier among Iranian students based on gender differences. It shows that women utilize intensifier about twice as much as men. It is due to the fact that society does not allow women to show their power and position. Moreover, Iranian women are faced with another social limitation, that is, the dress code which might put them in a more limited and inferior position and might deprive them of the chance to establish their social status. Baron has mentioned that language is used as one of the means of distinguishing gender differences in almost all societies: as such a lot of researchers have elaborated women's speech as being different from the speech of men (1986).

Intensifier as any other linguistic feature develops and changes through time. Murphy (2010, p. 111) states that the rate at which intensifier change is among the most rapid of linguistic element. Based on the researches stated before, the realization of intensifiers in Banyumasan, a dialect of Javanese language, has not been conducted. In fact, intensifier is a productive linguistic feature in Banyumasan which is often utilized to gain various purposes. Thus, different intensifiers are chosen. This article reveals the linguistic realization of intensifier in Banyumas dialect, a substandard of Javanese language.

\section{METHOD}

This research belongs to qualitative research since it tries to reveal language phenomena and present it in qualitative explanation without considering statistics. Cresswell (1994) mentions that a qualitative research is an exploratory research where the researcher explores a single entity or phenomenon (the case) bounded by time and activity and collects detailed information by using a variety of data collection procedures during a sustained period of time. Data are gathered from natural conversation among Banyumas native speakers. There are two techniques in collecting data. First, we are actively involved in natural conversation with Banyumas native speakers and invite them to produce intensifiers. Second, we secretly record the conversation to get a natural setting. Natural occurring data is preferable in qualitative research (Hammersley, p. 1992).

Having collected the data both by recording and note-taking, classification is conducted. Data are classified based on the type of intensifier, whether it is lexical item or reduplication. The lexical items consist of bangèt and pisan.In addition, specific lexical items include réa, régéng, lèdèr, njilèp, cirut, lècit, kècu, kèthuwèk. Reduplication contains full reduplication partial reduplication, reduplication with vowel change, reduplication of the final syllable of the stem.

Data are presented by using Max Planck's convention for interlinear morpheme-by-morpheme glosses (2015). We use word-by-word alignment in which interlinear glosses are left-aligned vertically so that each meaning can be clearly shown. An explanation is given for each data in relation to the theoretical frame work to answer the research question.

\section{RESULT AND ANALYSIS}

The result shows that intensifiers in Banyumas dialect are realized into lexical items and reduplication. Lexical items are subdivided into general lexical items and specific lexical item. Reduplication is realized into full reduplication and partial reduplication. Partial reduplication consists of reduplication with vowel change and reduplication of the final syllable of the stem.

\section{A. Lexical Items}

Lexical items used to show intensity in Banyumas dialect are classified into two categories, general and specific ones. The general intensifiers include the word bangèt and pisan. The use of bangèt and pisan are similar to English intensifiers very/ really/ awfully. In addition to the general ones, the specific ones consist of réa, régéng, lèdèr, njilèp, cirut, lècit, kècu, kèthuwèk. Thus, the discussion of lexical items used as intensifiers in Banyumas dialect is elaborated in two major categories. Before analyzing the specific lexical items, the general lexical items are depicted as follows. 
General words used to show intensifier in Banyumas dialect are bangèt and pisan. The sentences below show the use of banget and pisan.
(1) umahé gèdhé bayèt
house (his/her) big very
His house is very big.
$\begin{array}{lll}\text { (2) umahé } & \text { gèdhé } & \text { pisan } \\ \text { house (his/her) } & \text { big } & \text { very }\end{array}$

His house is very big.

From (1) and (2) above, it can be seen that the word bangèt and pisan have a clear semantic meaning 'very'. Consequently, bangèt and pisan are free variation since they can replace each other and construction (1) and (2) are acceptable in Banyumas dialect without changing the meaning. Bangèt and pisan are general lexical items to show intensity in Banyumas dialect. Both bangèt and pisan are placed after adjective gèdhé.

Bangèt as an intensifier is rarely found in front of adjective as it is found in (1b).
(1b) umahé bayèt gèdhéné
house (his/her) big very

His/her house is very big.

In spite of the fact that (1b) is acceptable and understandable for Banyumas native speakers, the construction (1b) is not commonly used and the similar thing happens to pisan.

The use of bangèt and pisan in (1) and (2) are similar to English intensifiers such as really, very and awfully. They indicate the boosted conditioned (the target of the intensifier). As it has been mentioned, intensifiers are functioned to boosting the meaning of another expression, however, they must be associated with a scalar and non-binary property (Eckardt, 2009). Compare sentence (1) and (1c).

$\begin{array}{lll}\text { (1) umahé } & \text { gèdhé } & \text { bayèt } \\ \text { house (his/her) big } & \text { very } \\ \text { His house is very big. } & \\ \text { (1c) bocahé } \quad \text { lanan } & \text { bayèt } \\ \text { Boy } & \text { man } & \text { vey } \\ \text { The boy is very man. } & \end{array}$

Sentence (1) shows the use of intensifier to boost the modified expression (a very big house). It shows the scalar of bigness. By using intensifier bangèt, speaker wants to inform that the house is very big. Big as well as other adjective have scalar categories, such as, bigger and the biggest. The combination of intensifier (bangèt) and other entity (umahé) indicate the quantitative degree of the entity, it means that the entity posses the quality described in the adjective. It is acknowledged as degree modification (Kennedy and McNally, 2005).

Sentence (1c) indicates that the predicate lanay does not match degree modification as the predicate has discrete character. In Banyumas dialect, lanay 'male' is the opposite of wadon 'female'. lanay and wadon are binary sex properties in Banyumas dialect. It is not common for Banyumas speaker to utter lanay bayèt to express the degree of maleness. It indicates that intensifier does not match the targeted predicate, to be specific the predicates which carries binary properties.

In addition to general lexical items, specific lexical items are also used as intensifier in Banyumas dialects. To mention a few are réa, régéng, lèdèr, njilèp, cirut, lècit, kècu, kèthuwèk. The sentences below show the realization of the specific word to show intensity.
(3) sègané
rice
sèpa
tasteless very
réa

The rice is very tasteless.

Sentence (3) shows that the food is tasteless. It is explicitly mentioned in the sentence that réa is used to show intensity. Instead of using the word banget which also means very, the word réa is used by the speaker to show that the food is very tasteless. The word réa is tightly used with the word sèpa. It cannot be used with other word, for example, sugih 'rich'. There is no construction like *sugih réa in Banyumas dialect.

Similar to réa, the word régéng also has similar meaning 'very' as it can be seen from (4).
(4) janané
anta
tasteless
régén

The food is very tasteless.

Sentence (4) indicates that the word régéng is strongly related to anta. Speakers cannot say *anta rea in Banyumas dialect because *anta rea is not acceptable for native speakers. Even though the word anta is closely-related to régéng, it still can be followed by bangèt and pisan. Thus a speaker may say sentence (5) and (6)
(5) jạané
anta
food tasteless
bangèt
The food is very tasteless.
$\begin{array}{cll}\text { (6) janané } & \text { anta } & \text { pisan } \\ \text { food } & \text { tasteless } & \text { very }\end{array}$ 
The food is very tasteless.

The word lèder is also used as intensifier with specific circumstance. It is only used with the word pait as it is shown in (7).
(7) jamuné
pait
lèdèr
herbal drink
bitter
very

The herbal drink is very bitter.

Sentence (7) clearly shows that the word lèder is only used with the word pait to intensify the degree of bitterness. By saying jamuné pait lèdèr, speakers want to inform that the herbal drink is very bitter. If sentence (7) is transformed into (8), it is still acceptable in Banyumas dialect.

$\begin{array}{lll}\text { (8) jamuné } & \text { pait } & \text { bayèt } \\ \text { herbal drink } & \text { bitter } & \text { very }\end{array}$

The herbal drink is very bitter.

Sentence (8) highlights that the word bangèt is a general intensifier in Banyumas dialect since the replacement of lèdèr into bangèt does not change the meaning of the construction. In a simple way, it can be explicitly mentioned that the construction of pait lèdèr and pait bangèt are acceptable in Banyumas dialect.

Sentence (9), (10), (11), (12), and (13) shows the realization of njilèp, cirut, lècit, kècu, kèthuwèk consecutively.

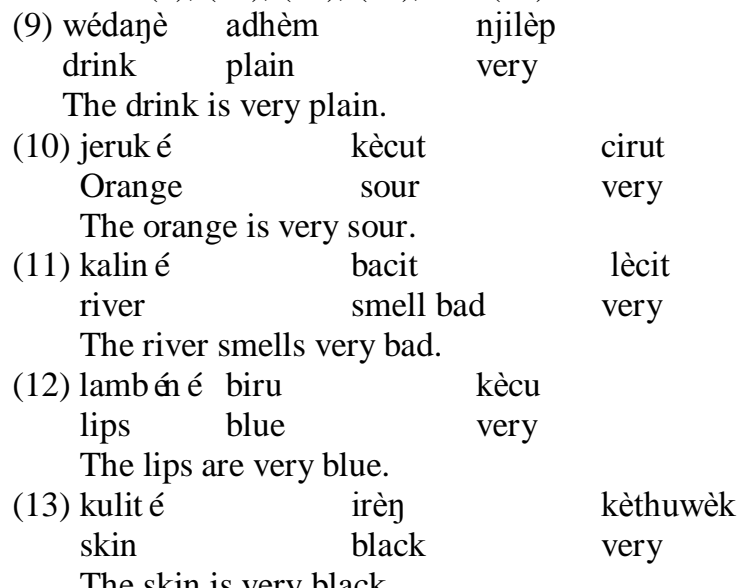

The words of njilèp, cirut, lècit, kècu, kèthuwèk in (9), (10), (11), (12), and (13) can be replaced by the word bangèt and pisan. In spite of the fact that the word kèthuwèk and kecu are used to intensify color as they can be found in (12) dan (13), they cannot replace each other. To intensify blue color, speaker use kecu instead of kèthuwèk and the word kèthuwèk is used to intensify black color, not the other way around. To be exact, the construction of *irèng kecu and * biru kèthuwèk are not acceptable in Banyumas dialect.

Similar to general lexical items in construction (1), (2), (5), (6) and (8); specific lexical items are also placed after adjective as it can be seen in construction (3), (4), (7), (9), (10), (11), (12), and (13). It can be inferred that intensifiers in Banyumas which consists of general lexical items and specific lexical items are placed after adjective. Basically intensifier in Banyumas dialect is used to intensify a condition. It is in accordance with Quirk et.al (1985: 439) who divides intensifiers into three semantic categories: emphasizers, amplifiers, and downtowners. They demonstrate that intensifiers do not only significantly point out intensification and only show a point on the intensity scale which may be high or low.

\section{B. Reduplication}

Reduplication can be utilized to show intensity in Banyumas dialect. It is realized into full reduplication and partial reduplication. Stewart (2001: 126) states that reduplication is a process of forming new words either by doubling an entire free morpheme (total reduplication) or part of it (partial reduplication). There are some constructions in Banyumas dialect using full reduplication to express intensity.

Sentence (14) shows the use of full reduplication as intensifier.
(14) tandurané ijo plants green royo-royo very

Royo-royo is used to intensify the condition of green color. By stating royo-royo, speakers want to intensify the condition of the plants. Royo-royo still can be replaced by the word bangèt or pisan without changing the meaning. Therefore, sentence (15) and (16) are acceptable in Banyumas dialect.

$\begin{array}{lll}\text { (15) tandurané } & \text { ijo } & \text { bayèt } \\ \text { plants } & \text { green } & \text { very } \\ \begin{array}{c}\text { The plants are very green. } \\ \text { (16) tandurané }\end{array} & & \\ \text { plants } & \text { ijo } & \text { pisan } \\ & \text { green } & \text { very }\end{array}$


The plants are very green.

Linguistically, it is widely known that reduplication has several different functions in some languages. In Banyumas dialect, reduplication is used as an intensifier. Besides, it is also used as a plural marker as in the construction bocahbocah means 'children'. Reduplication as a plural marker can also be found in Indonesian (Bahasa Indonesia). Anakanak means 'children' in Bahasa Indonesia. In Tagalog, reduplication is used as a future marker. A construction bili which means 'buy' becomes bibili in its future form 'will buy'.

Full reduplication to show intensity is also depicted by sentence (17).

$\begin{array}{clll}\begin{array}{c}\text { (17) layanané } \\ \text { kite }\end{array} & \text { mabur } & \text { dhuwur } & \text { laur-laur } \\ & \text { fly } & \text { high } & \text { very }\end{array}$

The kite flies very high.

Laur-laur is used to intensify the height of the kite. Intensifier is used by speakers to boost the condition of something. In other way, intensifier carries emotional meaning even though it does not contribute to the propositional meaning. To inform that the kite flies high, speakers do not have to utilize an intensifier, however, when they want to add emotional content to their utterance, intensifier is highlighted.

Sentence (18) and (19), point out the use of full reduplication as intensifier in Banyu's dialect.
(18) adhiné mankat sèkolah ésuk his/her sister go school morning

His sister goes to school very early in the morning.

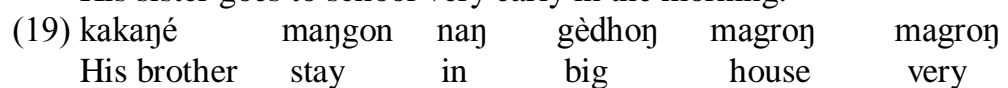

His brother stays in a very big house.

Partial reduplication is also used as an intensifier device in Banyumas dialect. It is employed by reduplication with vowel change and reduplication of final syllable of the stem. Reduplication with vowel change can be seen in the sentence (20), (21), and (22).

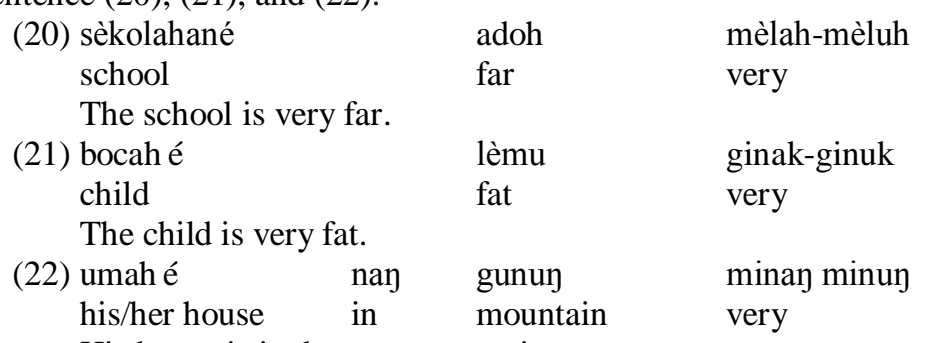

His house is in the very mountain.

Sentence (20), (21), and (22) show the use of partial reduplication with vowel change as intensifier in Banyumas dialect. It can be seen that vowel [a] change into [u] in mèlah-mèluh ginak-ginuk, minang minung which means that reduplication with vowel change happens. Th

Another form of partial reduplication found in Banyumas dialect intensifier occurs when the final syllable of the stem is repeated. Those are uncovered by sentence (23), (24), and (25).
(23) woy tuwané mlarat jèrat His/her parents poor very His/her parents are very poor.
(24) nyon apal kècépal urutané I very much remeber order I remember the order very much
(25) pananané wutuh njètuh food untouched at all
The food is untouched at all.

Construction mlarat-jèrat is formed by reduplicate the final syllable of the stem mlarat. Mlarat means 'poor'. It has two syllables mla- and -rat. Jerat is formed by adding je- before the final syllable -rat and becomes jerat. Similar to mlarat-jerat, apal kècépal is also formed by reduplicate the final syllable of the stem apal. Apal has two syllables aand -pal. By adding kècé- before - pal, kècépal is formed. Apal means 'remember'.

Intensifiers in reduplication form, whether it is full reduplication or partial reduplication (reduplication with vowel change) undergo desemanticization which means the construction lose its meaning content (Heine, 2003, p. 279). Those constructions laur-laur, magrong-magrong, royo-royo, melah-meluh, ginak-ginuk, and minang-minung do not have any semantic content. Thus, it can be highlighted that intensifiers in full reduplication and partial reduplication (reduplication with vowel change) experience grammaticalization because lexical items become functional or grammatical items.

Intensifier is used by speakers to show the emotional content in their utterances. By adding emotional content to their utterance, speakers want to convey more than just referential meaning (Holmes, 2006). Affective meaning is being employed by speakers to some extent. Speakers may want to show their affection or to shorten the distance with the 
interlocutors. The tendency of using affective function instead of referential functions has become the characteristic of women's speech. It is in line with Baron (1986) who has summarizes that language is used as one of the means of distinguishing gender differences in almost all societies; as such, many researchers have described women's speech as being different from the speech of men.

\section{CONCLUSION}

The result reveals that intensifiers in Banyumas dialect are realized into two linguistic categories, lexical items and reduplication. Lexical items consist of general lexical items and specific lexical items. The general lexical items can replace the specific lexical item but not vice versa. Both of them are placed after adjective. Thus, it can be inferred that lexical items such as bangèt and pisan experience degree of modification as long as they are attached to non-binary properties.

Reduplications which are used as intensifiers are classified into full reduplication and partial reduplication. Reduplication with vowel change undertakes grammaticalization because lexical items which are used in this reduplication lose their semantic content. On the other hand, grammaticalization does not happen to general lexical items due to the fact that they still have their semantic content when they are used as intensifiers.

The result does not quantitatively show the occurrence between general lexical items and specific lexical items to show intensity in Banyumas dialect. However, it can be explicitly inference from the discussion that the general lexical items (bangèt and pisan) have broader distribution. A further research on the use of bangèt and pisan can be conducted to quantitatively show the distribution of those intensifiers.

The research does not clearly state the context of occurrence in which what situation certain intensifiers are used whether the general lexical items are used in formal or informal situations, or spontaneous conversation and so forth. By considering the context of utterance, a deeper insight of intensifiers in Banyumas dialect can be deliberately elaborated. Context can be further explained by considering who speaks what to whom and where. Gender and age can be variables in the further possible research of Banyumas intensifiers.

\section{REFERENCES}

[1] Baron, D. (1986). Grammar and Gender. New Heaven: Yale University Press.

[2] Beltrama, A. and Bochnak, M. R. (2013). Intensification without degrees crosslinguistically. Ms.University of Chicago.

[3] Brown, Emma M. (2014). Wicked intense: the grammaticalization of wicked and other intensifiers in New Hampshire. In Honor Theses. University of Hampshire.

[4] Brown, Esther L and Mayra Cortés-Torres. (2013). Puerto Rican Intensifiers: Bien/Muy Variables pp 11-19. In Carvalho and Baudrie (Eds). Selected Proceedings of $6^{\text {th }}$ Workshop on Spanish Sociolinguistics.

[5] Chambers, J.K. \& Peter Trudgill. (1994). Dialectology. Great Britain: Cambridge University Press.

[6] Creswell, John W. (1994). Research Design: Qualitative \& Quantitative Approaches. London: SAGE Publications.

[7] Eckert, P. (2012). Three waves of variation study: The emergence of meaning in the study of variation. Annual Review of Anthropology, 41:87-100.

[8] Heine, B. (2003). Grammaticalization. In B.D. Joseph and R.D. Janda (Eds). The Handbook of Historical Linguistics (575-601). Massachusetts: Blackwell Publishing Ltd.

[9] Hammersley, M. (1992). What's Wrong with Ethnography? Methodological Explorations. London: Routledge.

[10] Holmes, Janet. (2006). An Introduction to Sociolinguistics. England: Pearson Education Limited.

[11] Ito, Rita and Sali Tagliamonte. (2003). Well Weird, Right Dodgy, Very Strange, Really Cool: Layering and Recycling in English Intensifiers. Language in Society 32(2), 257-279.

[12] Kennedy, C. and McNally, L. (2005). Scale structure, degree modification and the semantics of gradable predicates. Language, 81(2):345-381.

[13] Koentjaraningrat. (1984). Kebudayaan Jawa. Jakarta: Balai Pustaka.

[14] Macaulay, Ronald. (2006). Pure Grammaticalization: The Development of a Teenage Intensifier. Language Variation and Change 18(3): 267-283.

[15] McNabb, Y. (2012). Cross-categorial modification of properties in Hebrew and English. In Chereches, A., editor, Proceedings of Semantics and Linguistic Theory (SALT) 22, pages 365-382. eLanguage.

[16] Murphy, Bróna. (2010). Corpus and Sociolinguistics: Investigating Age and Gender in Female Talk. Amsterdam: Benjamins.

[17] Quirk, R., Greenbaum, S., Leech, G., and Svartvik, J. (1985). A Comprehensive Grammar of the English Language. London: Longman.

[18] Rickford, John, Thomas Wasow, Arnold Zwicky, and Isabella Buchstaller. (2007). Intensive and Quotative All: Something Old, Something New. American Speech 82(1), 3-31.

[19] Sardabi, Narges and Akbar Afghari. (2015). Gender Differences in the Use of Intensifiers. Journal of Applied Linguistics and Language Research 2(7): 203-213.

[20] Stewart Jr, Thomas W and Nathan Vaillette. (2001). Language File: Material for an Introduction to language and linguistics $8^{\text {th }}$ edition (ed). Ohio: Ohio State University Press.

[21] Tagliamonte, Sali. (2008). So different and pretty cool! Recycling intensifiers in Toronto, Canada. English Language and Linguistics 12(2), 361-394

[22] Wedhawati dkk. (2006). Tata Bahasa Jawa Mutakhir. Yogyakarta: Penerbit Kanisius 
Chusni Hadiati was born in Banyumas, May 8, 1980. She got her doctoral degree from Universitas Indonesia majoring in linguistics in 2016.

She is a researcher and lecturer in English Department, Jenderal Soedirman University, Purwokerto, Central-Java. Her researches are mainly on morphology, pragmatics, stylistics, semiotics, language policy. Currently she is working on her research of language policy on the existence of Bahasa Indonesia and foreign languages in Indonesia's public space. 